\title{
School Based Management Within The Framework of Autonomy at SMP Negeri 1 Rejang Lebong
}

\author{
Hamengkubuwono \\ Institut Agama Islam Negeri (IAIN) Curup \\ hamengku7@gmail.com
}

\begin{abstract}
School-based management is an educational management concept that provides autonomy for a school in organizing the continuity of education according to the needs of the school context. By applying a case study, this study was conducted to reveal the implementation of school-based management, along with its supporting and inhibiting factors, at SMP Negeri 1 Rejang Lebong, Curup, Bengkulu. All potential parties at school that could provide the expected data were involved purposively as the subjects. Data garnered from them were solicited using interviews and observations, which were then triangulated and analyzed using an interactive model. The interactive model worked in four components, namely data collection, data condensation, data presentation, and drawing a conclusion. The findings showed that had implemented school-based management functions properly, including planning, organizing, implementing and supervising the aspects of human resource management, student management, facilities and infrastructure management, financial management, curriculum and learning management, and management of school and community relations. Supporting factors for the implementation of school-based management included the participation of committees, parents, community at school, complete teaching staff, facilities and infrastructure. Meanwhile, the inhibiting factor was that some students still did not obey the school rules.
\end{abstract}

Keywords: Management, School, School-based Management, School autonomyoriented management

Abstrak: Manajemen berbasis sekolah adalah sebuab konsep manajemen pendidikan yang memberikan otonomi bagi sebuah sekolah dalam mengorganisasikan keberlangsungan pendidikan sesuai dengan kebutuhan konteks sekolah tersebut. Dengan menerapkan penelitian studi kasus, penelitian ini dilakukan untuk. mengungkap pelaksanaan manajemen berbasis sekolah, beserta factor pendukung dan penghambatnya, di SMP Negeri 1 Rejang Lebong, Curup, Bengkulu. Seluruh perangkat sekolah yang berpotensi memberikan data dilibatkan secara purposive sebagai subjek. Data atau informasi dari mereka digali menggunakan teknik, wawancara dan observasi, yang selanjutnya data ditriangulasikan dan dianalisa menggunakan model interaktif. Model interaktif bekerja dalam empat komponen, yaitu pengumpulan data, pemadatan data, penyajian data, dan penarikan simpulan. Hasil penelitian menunjukkan bahwa telah dilaksanakan fungsifungsi manajemen berbasis sekolah dengan baik antara lain perencanaan, pengorganisasian, pelaksanaan dan pengawasan dalam aspek manajemen SDM, manajemen peserta didik, manajemen sarana dan prasarana, manajemen keuangan, manajemen kurikulum dan pembelajaran, serta manajemen bubungan sekolah dan masyarakat. Faktor pendukung implementasi manajemen berbasis sekolab diantaranya peran serta komite, orang tua, masyarakat dalam sekolah, lengkapnya tenaga pendidik, sarana dan prasarana. Sedangkan factor penghambatnya yaitu beberapa siswa yang tidak mematubi disiplin dan aturan sekolah.

Kata Kunci: Manajemen, Sekolah, Manajemen berbasis sekolah, Manajemen berorientasi pada otonomi sekolah 


\section{INTRODUCTION}

The implementation of education in Indonesia was initially centralized, making the process of providing education in Indonesia not supporting the quality of education produced (Aisyah\& Ali, 2018, Salamat, A., Krpalek, D., \&Javaherian, H, 2020). Human Resources, in this case qualified educators, are scattered in many cities. The consequences of the centralized education system are decisions that are followed completely from the center, such as a uniform curriculum regardless of its relevance for the lives of students and the surrounding community (Munajat, 2016; Pasaribu, 2017). The Centralistic System gave birth to phenomena including: uniformity of school management from the planning, management and evaluation processes to school development and learning models, the quality of students and educators who lack initiative and lack of creativity, weakening local culture (Pasaribu, 2017). To change this, the government took a policy by changing the national education system that was originally centralized to a decentralized system (Akbar, 2019).

In Law Number 20 of 2003 concerning the National Education System, it is stated that education must adhere to many standards, including education that must be implemented in a democratic and just manner and not be discriminatory, and that education must respect human rights. religious values, cultural values, and pluralism with one institutional unit. with a framework that is transparent and multi-meaning. Education must be implemented as a continuous process of nurturing and inspiring students by being a model, building enthusiasm, and encouraging student innovation in the learning process (Holmes, et.al. (2020). Decentralization in the education sector means the transfer of power by the center to the provincial and local education management apparatus as an extension of the central apparatus to improve the efficiency of education management in the regions (Hakim, 2016; Kurnia, 2018). An example of the division of educational affairs according to Government Regulation of the Republic of Indonesia Number 37 of 2007: The central government makes policies for the development and determination of national education standards (content, competency processes for graduates, educational staff, facilities and infrastructure, financial management and education assessment). Provinces allocate potential teaching staff and education personnel in the regions, districts/cities grant establishment permits and revoke permits for local primary and secondary education units (Yahya, 2017).

One model of decentralized education is School Based Management (Kurnia, 2018). SBM is a school management approach that seeks to give school principals maximum authority to coordinate, regulate and organize schools while increasing community involvement. With the existence of SBM, it is hoped that it will be able to improve the quality of education which is also 
oriented towards the process of implementing education, not only oriented to the input that has so far occurred in schools in Indonesia.

In the SBM model, information must be distributed to all relevant elements in schools and school stakeholders (Ajefri, 2017; Maskur, 2017; Pasaribu, 2017). Parties related to school management know the vision, mission strategy, goals and objectives of the school, finance and cost structure of issues around the school, school performance is only owned by top leaders. SBM also seeks to improve school performance by giving schools greater authority and responsibility, which is applied based on good school management standards such as engagement, openness and accountability. Quality, effectiveness, reliability, sustainability and educational creativity are examples of school achievements.

The policies contained in the concept of School Based Management (SBM) should be interpreted as a form of system autonomy and education management which aims to improve the quality and quality of education for all levels of society, not to transfer responsibility from the government to the hands of the community. School-based management is a management style that provides more power to the principal and allows everyone in the school to participate in decision making (Yahya, 2017). School residents include: school principals, teachers, students, parents of students, education personnel and the community.

The main objective of SBM is to improve the performance, quality and equity of education (Arifin, 2020). Flexibility in managing existing capital, community interaction, and simplification of the bureaucracy contribute to increased productivity (Muniroh\&Muhyadi, 2017). Parental involvement, effective school management, increased teacher professionalism, rewards and punishments as restraints, and other factors that can foster a conducive environment all contribute to quality growth (Botha, 2007). Equitable education can be seen in the growing participation of the people, especially those who are capable and caring, while those who are less fortunate will become the responsibility of the government. The objectives of MBS above are in accordance with Law Number 20 of 2003 concerning the National Education System, namely: "National education aims to develop the potential to become human beings who believe and have devotion to God Almighty, have noble character, are healthy, knowledgeable, competent, creative, independent and become a democratic and responsible citizen. The most important thing in the implementation of School Based Management is a management review of the components of the school itself (Briggs \&Wohlstetter, 2003). Curriculum and teaching programs, teaching staff, students, funding, educational facilities and infrastructure, school management and community relations, and special 
education services are elements that must be managed adequately in the context of SBM.

The community assesses the success of schools by the quality of output of their students (Warsah et al., 2020). Benchmarks for the success of students are assessed from academic scores such as National Final Examination and nonacademic scores such as arts and sports. Quality is determined by input, process, and output (Montecinos, C., Cortez Munoz, M., Campos, F., \& Godfrey, D. 2020). The quality of school output is influenced by the readiness of the input and the educational process. Quantities of school input include the number of teachers, school capital, materials, facilities and infrastructure. The quantity of school output, among others, consists of the number of students who graduate each year. Improving the quality of school output cannot be separated from the ability and quality of teaching staff.

A school is said to be productive if the number of graduates is more/increased this year than in the previous year with the same input (number of teachers, facilities, etc.). Effectiveness is a metric that reflects the extent to which targets can be achieved. Effectiveness is defined as the actual result divided by the expected result in the form of an equation. For example, the ideal National Final Examination (NFE) score is 60, but the NFE obtained by students is only 45 , so the effectiveness is $45: 60=75 \%$. Efficiency can be classified into two, namely internal efficiency and external efficiency. Internal efficiency shows the relationship between school output and the input used to produce school output. Internal school efficiency is usually measured by cost effectiveness. Every cost-effectiveness assessment always requires two things, namely an economic assessment to measure the cost of input (input) and an assessment of learning outcomes. For example, if the costs are the same, but this year's NFE is better than the previous year, it can be concluded that this year the school is more efficient internally than last year.

External efficiency is the relationship between the costs used to produce graduates and the cumulative benefits (individual, social, economic and noneconomic) that are obtained outside of school after a long period of time. To measure external efficiency, the tool used is cost analysis. For example, Junior High School 1 Rejang Lebong and Junior High School 2 Rejang Lebong use the same fees each year, but Junior High School 1 graduates earn more than Junior High School 2 Rejang Lebong after they work. With these results, it can be concluded that Junior High School 1 Rejang Lebong is more efficient externally than Junior High School 2 Rejang Lebong.

Changing the education management paradigm from centralized to decentralize is certainly not an easy thing (Akbar, 2019). Changes in the system 
used require adaptation at each educational institution in accordance with the existing social and cultural conditions, environment and human resources. If previously schools only carried out orders from the ruling government, at this time schools were given the freedom and authority to manage their institutions to meet the needs and demands of society as well as competition in the era of globalization. Can the release of schools in managing their policies improve the quality of education? Whether schools can improve the quality, effectiveness, efficiency, productivity, and educational innovation with the new system?

The problem that arises to improve the quality of education lies not only in management. The existing human resources in an institution also determine how education can progress and develop (Muniroh\&Muhyadi, 2017). The teacher as an educator is required to be professional so that what becomes the vision and mission of an educational institution can be realized. The regulations regarding the signs or requirements to become educators are actually quite clear. Article 40 paragraphs (2) of Law No.20/2003 concerning the National Education System (NES) explains, for example, educators and education personnel must be role models and uphold the good name of institutions, professions and beliefs. Likewise in PP 19/2005 concerning National Education Standards (NES) and PP 74/2008 that a teacher must have at least four basic competencies, namely pedagogical, personal, professional, and social competencies. This means that a teacher is required not only to be skilled in technical-academic terms but also to be a warm, pleasant and authoritative person.

The quality of education is closely related to the quality of the teaching force (Salehi\&Jafari, 2015). There are four factors that cause the low quality of teachers: (1) Due to the low level of welfare, many teachers are not fully serious about their profession; (2) lack of professional standards for teachers as required in developed countries; (3) lack of teacher motivation in improving self-quality because the expected teacher does not conduct research like lecturers in tertiary institutions; and (4) the possibility of private universities producing native or intermediate teachers, regardless of their potential performance in the field (Wu et al., 2017)

In the definition of SBM, efforts to empower educators and education personnel include efforts to increase the efficiency of teaching and education personnel, as well as cooperation and communication (Nasution\&Pasaribu, 2020). The coordination carried out by the principal with educators and the community can be vertical, horizontal, functional and diagonal (Admin \&Zaman, 2017). Coordination can also be done internally and externally and continuously as a consolidation step in strengthening the Educational Institution to achieve a goal. For example, holding informal meetings with officials, holding 
meetings, both coordination meetings between principals, schools and teachers, with committees and with parents of students. Answering that question requires an in-depth study. Regardless of the management system used, the school as an educational institution has a big responsibility in printing the future of the nation, in any way it is required to develop and give birth to new innovations in the world of education and to create a better generation and make our country stand equal to the State. Others (Hamiloglu\&Temiz, 2012; Spengler, 2015).

To further examine how the role of School Based Management in improving the quality of education with regard to the quality of its teaching staff is to examine directly how the application of SBM at SMP Negeri 1 Rejang Lebong. SMP Negeri 1 Rejang Lebong is one of the favorite schools in the city of Curup. The progress achieved by these educational institutions cannot be separated from the role of the principal as a manager in managing management so that it can attract the interest of the community to send their children to these two institutions. Likewise, the quality of the teaching staff they have, including all of them has a bachelor's degree (S2).

Improving the quality of teaching staff at Junior High School Negeri 1 Rejang Lebong is carried out with several strategies; first, improving the quality of teachers, which is a government program. Second, improving the quality of teachers in relation to institutions. Third, improving the quality of teachers by using cross-institutional media". The use of cross-agency media was carried out at Junior High SchoolNegeri 1 Rejang Lebong, when the researcher asked about the role of the community in saying that the community played a big role in school. For example, there are usually external parties such as the police providing materials to students, prisons, tax offices, health. The community also helps Junior High SchoolNegeri 1 Rejang Lebong in improving the quality of the teaching force, such as giving donations to schools in the form of materials and thoughts, in the form of the school committee. Meanwhile, regarding the improvement of the quality of teaching staff, Junior High School Negeri 1 Rejang Lebong held training in making IT-based questions, making PTK, making learning media, and so on. Starting from the description above, the author is encouraged to examine more deeply the following problem formulations: 1. how is the application of School Based Management in improving the quality of teaching staff at Junior High School Negeri 1 Rejang Lebong?

\section{RESEARCH METHODS}

This research applies case study research (Creswell, 2007; Yazan, 2015) which aims to describe the application of School-Based Management in improving the quality of teaching staff at Junior High School 1 Rejang Lebong. 
This research was conducted at Junior High School 1 Rejang Lebong. The reason behind choosing this school as the background is because Junior High School 1 Rejang Lebong was chosen as one of the best schools in Bengkulu Province. In this study the data obtained using purposive sampling technique (Ary et al., 2010; Fraenkel et al., 2012) based on the source can be classified as primary and secondary data. Primary data sources include the Principal of Junior High School 1 Rejang Lebong, Deputy Principals (Curriculum, Public Relations, Student) Junior High School 1 Rejang Lebong, teachers at Junior High School 1 Rejang Lebong, and students at Junior High School 1 Rejang Lebong. Furthermore, Secondary Data includes documents, records and reports as well as official archives. The relationship between researchers and informants is very much determined by the extent to which the abilities and skills that the researcher has fostered from the beginning of entering the research location. Then the data sources that come from the documentation are selected based on the relevance of the research title such as notes, recorded images/photos, and the results of observations that are related to the focus of this research.

Data collection in this study was carried out using two techniques, namely, interviews and observation (Gall et al., 2003). Interviews were conducted with informants who were considered to be the most knowledgeable or implementers in planning, implementing control, and efforts to improve the quality of teaching staff at Junior High School 1 Rejang Lebong. Observations were made to see and understand and draw conclusions on management activities that occur in the implementation of School-Based Management in improving the quality of teaching personnel at Junior High School 1 Rejang Lebong both in the active role of the community, the leadership of the school principal, and efforts to improve the quality of teaching staff which the researchers can observe directly, such as, how to prepare plans, how to control activities, and how to improve the quality of teaching staff, as well as various activities related to the process of implementing School Based Management in improving the quality of teaching staff at Junior High School 1 Rejang Lebong.

The raw data from interviews and observations were analyzed using an interactive model as suggested by Miles et al. (2014). Data analysis includes four components, namely, data collection, data compacting, data presentation, and drawing conclusions. Regarding data collection, as previously explained, data were collected through interviews and observations. The two data sets (transcripts from interviews and field notes) were then compared and mapped with each other as an effort to triangulate data in order to minimize data bias (Jakob, 2001). Regarding data compaction, all raw data are grouped according to representative themes. Regarding the data presentation component, the raw data that have been grouped based on their respective theme groups are then 
selected the most representative to be presented in this article. In this article, data is presented in the form of interview excerpts, illustrations and descriptions of observations, theoretical arguments, explanations of the data, and researcher interpretations followed by data discussion. Furthermore, all data are concluded in a comprehensive and representative manner.

\section{RESULTS AND DISCUSSION}

Based on data analysis sourced from triangulated interviews and observations, research results were obtained such as the following elaboration:

\section{Curriculum Management and Learning}

Curriculum managementand learning includes planning, organizing, implementing and monitoring activities. Regarding planning, schools are given authority (autonomy) in developing curriculum and learning according to school conditions. Curriculum development involves school principals, communities, school committees and supervisors. Junior High School 1 develops a national curriculum, there is no local content. The curriculum and learning tools are arranged based on the academic calendar that has been determined by the National Education Office. Schools describe in more detail the content of the curriculum into annual programs, semester programs, syllabus, lesson plans, MCC, and lesson schedules.

Regarding organizing, organizing in the form of a division of teaching duties and the organizational structure of Junior High School 1 Rejang Lebong. Regarding the implementation, the learning process at Junior High School 1 Rejang Lebong uses the method of discussion, question and answer, inquiry, basic learning, using the facilities that have been provided. The teacher uses learning aids such as teaching aids, LCD, pictures, posters, pictures, student worksheets and modules. Teachers provide opportunities for students to be creative, active, interactive and independent. Evaluation is carried out at the end of each lesson in writing and orally. The school has a talent and interest development program through extracurricular activities. Among others: English Club, Science Club, Mathematics Club, Social Club, Sports, Literacy, Islamic Youth Mosque (Risma), PMR, Scouts, Paspalsa, Wall magazine, Traditional Music, Dance, Poetry, Taekwondo, martial arts. These activities are trained by teachers except Tekwondo. Apart from extracurricular activities, the school has a counseling service program. Counseling services are carried out by counseling guidance teachers once a month.

Related to monitoring/evaluation, monitoring/evaluation is carried out to measure student success. Learning assessment includes an assessment of learning processes and outcomes. Process assessment is carried out during the 
learning process related to activeness, collaboration, creativity. Assessment of learning outcomes is carried out by carrying out formative tests and assignments. Based on the results of the evaluation, a follow-up was carried out in the form of remedials and enrichments. For students who have not met the minimum completeness criteria (MCC), a remedial is carried out. Meanwhile, students who have passed the MCC score are given enrichment. Remedial and Enrichment are given after the formative test. Student learning outcomes are given to parents. As a form of school responsibility to students. Student learning outcomes for one semester are reported in the form of report cards.

\section{Student Management}

Student management also includes planning, organizing, implementing and monitoring activities. Planning activities start from the student admission process. Admission of new students is carried out with a zoning and achievement system. Admission announcements are made via the Web and written announcements at Junior High School 1 Rejang Lebong. After admission, an orientation process for new students is carried out for the introduction of the school for new students which is carried out for 2 days. Related to organizing, organizing is carried out by dividing new classes of students. Class distribution is done randomly through a meeting of the teachers. Regarding service, service to students is carried out by paying attention to the talents and interests of students. Services in the form of daily services in schools and extracurricular services and competitions. In addition to services to students, students are also required to follow the school rules and classroom rules that have been agreed between students and teachers. Furthermore, regarding recording and reporting, the school records student data. The recording of student conditions is reported in the form of a student manual, student attendance list, student grade list, student transfer book, student statistics board and student report cards.

\section{Management of Educators and Education Personnel}

Junior High School 1 Rejang Lebong has a principal with a master's education background, 65 civil servant teachers, 6 honorary teachers, 5 administrative staff and 1 librarian. The management of teaching staff and education personnel consists of planning, organizing, implementing and supervising. In the planning aspect, the procurement of teachers and education personnel is carried out through the recruitment of civil servants and honorary staff and transfers from other schools. In the organizational aspect, organizing is done by dividing the teacher's assignments. The division of teacher duties is determined in the teacher council meeting. Meetings are usually held after class promotion. Regarding implementation, the management process in 
implementation is carried out by providing guidance and development of educators and educational personnel. Development is carried out by involving educators and education personnel to attend training. In the aspect of supervision, the principal carries out supervision at the beginning, middle and end of the semester. This is done to determine the readiness of learning devices and learning outcomes.

\section{Management of Facilities and Infrastructure}

Facilities and infrastructure at Junior High School 1 Rejang Lebong are quite adequate. Junior High School 1 Rejang Lebong has 30 study rooms, 1 library, 25 student toilets, 3 teacher toilets, 1 language laboratory, 1 science laboratory, 1 warehouse, 4 sports fields. Inventory records for facilities and infrastructure known as state-owned assets are reported annually to the National Education Office.

\section{Financing Management}

The source of funding for Junior High School 1 Rejang Lebong comes from the state. The principal is responsible for managing and supervising the use of funds effectively and efficiently and for evaluating existing programs in schools.

\section{School and Public Relations Management}

The school accommodates community aspirations through a school committee consisting of student guardians.

\section{Supporting and Inhibiting Factors for the Implementation of School- Based Management at Junior High School 1 Rejang Lebong}

The supporting factors for the implementation of SBM at Junior High School 1 Rejang Lebong include: complete teaching staff and many of them have S2 education, quality education personnel, complete facilities and infrastructure, adequate level of student intelligence, active participation of the school committee. The inhibiting factors include: the existence of some students who are disorderly and often violate regulations, the difficulty of gathering parents and school committee members in committee meetings.

As a discussion, school-based management provides autonomy to schools by involving school members and the community to manage existing resources to improve the quality of schools based on government policies (Hakim, 2016; Kurnia, 2018). Granting greater authority is expected to improve school independence and school quality (Pasaribu, 2017). In the implementation of school-based management, school functions carried out by the central government are decentralized to school principals (Pasaribu, 2017). Some of the 
functions that cannot be delegated to school principals are still under the authority of the central government, provincial and district education offices and others are delegated to schools (Ajefri, 2017; Akbar, 2019). The functions delegated to schools include: 1. Teaching and learning process, 2. Planning and evaluation of school programs, 3. Curriculum management, 4. Manpower management, 5. Facilities and infrastructure management, 6. Financial management, 7. Participant management students, 8. Community relations management, 9. School climate management.

In the context of this research, Junior High School 1 Rejang Lebong was the target of a comparative study from Junior High School 1 Pagaralam, Junior High School 1 Argamakmur, Junior High School 5 Bengkulu Tengah, Junior High School 2 Bnegkulu. In implementing school-based management, Junior High School 1 Rejang Lebong succeeded in the management of its students and human resource management.

\section{CONCLUSION}

In implementing school-based management, SMP Negeri 1 has carried out management functions well, including planning, organizing, implementing and supervising, namely in the fields of: HR management, student management, facilities and infrastructure management, financial management, curriculum management and learning, school and community relations management. Supporting factors for the implementation of school-based management include: the participation of committees, parents, the community in schools, complete teaching staff, facilities and infrastructure. While the inhibiting factors include: there are some students who do not obey the discipline and school rules.

\section{REFERENCE}

Admin, A., \& Zaman, B. (2017). Pembinaan Karakter Siswa Melalui Pelaksanaan Shalat Sunnah Dhuha di Sekolah Dasar Islam Terpadu Nur Hidayah Surakarta. TAMADDUN, $18(2), \quad 1$. https://doi.org/10.30587/tamaddun.v0i0.88.

Aisyah, \& Ali, M. (2018). Pendidikan Karakter: Konsep dan implementasinya. Prenada Media.

Ajefri, F. (2017). Efektifitas Kepemimpinan dalam Manajemen Berbasis Madrasah. Al-Idarah: Jurnal Kependidikan Islam, 7(2), 99-119. https://doi.org/10.24042/ALIDARAH.V7I2.2265.

Akbar, M. A. (2019). Konsep Manajemen Berbasis Sekolah dan Implementasinya. PAEDAGOG, 2(1). http://jurnal.staitapaktuan.ac.id/index.php/paedagog/article/view/10 1. 
Arifin, Z. (2020). Paradigma Studi Manajemen Berbasis Madrasah dan Guru Profesional. Muróbbî: Jurnal Ilmu Pendidikan, 4(1), 121-150. http://jurnal.iaibafa.ac.id/index.php/murobbi/article/view/305.

Ary, D., Jacobs, L. C., Sorensen, C. K., Walker, D. A., \& Razavieh, A. (2010). Introduction to research in education. In Measurement (8th ed., Vol. 4, Issue 43). Wadsworth, Cengage Learning. https://doi.org/10.1017/CBO9781107415324.004.

Botha, R. (Nico). (2007). School-based management: stakeholder participation and the impact of stakeholder values. Africa Education Review, 4(1), 28-41. https://doi.org/10.1080/18146620701412126.

Briggs, K. L., \& Wohlstetter, P. (2003). Key elements of a successful schoolbased management strategy. School Effectiveness and School Improvement, 14(3), 351-372. https://doi.org/10.1076/sesi.14.3.351.15840.

Creswell, J. W. (2007). Qualitative inquiry \& research design: Choosing among five approaches (2nd ed.). SAGE publications, Inc.

Fraenkel, J. R., Wallen, N. E., \& Hyun, H. H. (2012). How to design and evaluate research in education. McGraw-Hill Companies, Inc. https://doi.org/10.1017/CBO9781107415324.004.

Gall, M. D., Gall, J. P., \& Borg, W. R. (2003). Educational research: An introduction (7th ed.). Allyn and Bacon.

Grieco, L., Melnychuk, M., Ramsay, A., Baim-Lance, A., Turner, S., Wilshere, A., ... \& Utley, M. (2020). Operational analysis of school-based delivery models to vaccinate children against influenza. Health Systems, 1-10.

Hakim, M. N. (2016). Implementasi Manajemen Berbasis Sekolah Dalam Mewujudkan Sekolah Islam Unggulan. Nidhomul Haq: Jurnal Manajemen Pendidikan Islam, 1(2), 104-114. https://doi.org/10.31538/NDH.V1I2.7.

Hamiloglu, K., \& Temiz, G. (2012). The impact of teacher questions on student learning in efl. Journal of Educational and Instructional Studies in the World, 2(2), 1-8.

Holmes, L. C., Orom, H., Lehman, H. K., Lampkin, S., Halterman, J. S., Akiki, V., ... \& Wilding, G. E. (2020). A Pilot School-Based Health Center Intervention to Improve Asthma Chronic Care in High-Poverty Schools. Journal of Asthma, 1-16.

Kurnia, R. (2018). Konsep Manajemen Berbasis Sekolah (MBS) dan Implementasinya. $\quad$ FITRA, 2(2). http://jurnal.staitapaktuan.ac.id/index.php/fitra/article/view/33.

Maskur, M. (2017). Eksistensi dan Esensi Pendidikan Madrasah Di Indonesia. TERAMPIL: Jurnal Pendidikan Dan Pembelajaran Dasar, 4(1), 101119. https://doi.org/10.24042/TERAMPIL.V4I1.1807. 
Montecinos, C., Cortez Munoz, M., Campos, F., \& Godfrey, D. (2020). Multivoicedness as a tool for expanding school leaders' understandings and practices for school-based professional development. Professional Development in Education, 46(4), 677-690.

Munajat, N. (2016). Kebijakan Manajemen Berbasis Madrasah dalam Peningkatan Mutu Pendidikan Islam. Al-Bidayah: Jurnal Pendidikan Dasar Islam, 8(2). https://doi.org/10.14421/AL-BIDAYAH.V8I2.74

Muniroh, J., \& Muhyadi, M. (2017). Manajemen pendidik dan tenaga kependidikan di Madrasah Aliyah Negeri Kota Yogyakarta. Jurnal Akuntabilitas Manajemen Pendidikan, 5(2), 161. https://doi.org/10.21831/amp.v5i2.8050.

Nasution, S. N., \& Pasaribu, S. E. (2020). Pengaruh Pengawasan, Motivasi dan Disiplin Terhadap Kinerja Guru pada Yayasan Pendidikan Islam Terpadu Kuntum Bumi Rantauprapat. Maneggio: Jurnal Ilmiah Magister Manajemen, 3(1), 75-91. https://doi.org/10.30596/maneggio.v3i1.4741.

Pasaribu, A. (2017). Implementasi Manajemen Berbasis Sekolah Dalam Pencapaian Tujuan Pendidikan Nasional Di Madrasah. EduTech: Jurnal Ilmu Pendidikan Dan Ilmu Sosial, 3(1). https://doi.org/10.30596/EDUTECH.V3I1.984.

Salamat, A., Krpalek, D., \& Javaherian, H. (2020). Occupational therapy practitioners' perspectives about addressing mental health across school-based settings in Southern California. Journal of Occupational Therapy, Schools, \& Early Intervention, 1-12.

Salehi, M., \& Jafari, H. (2015). Development and validation of an EFL selfregulated learning questionnaire. Southern African Linguistics and Applied Language Studies, 33(1), 63-79. https://doi.org/10.2989/16073614.2015.1023503.

Spengler, S. (2015). Educators' Perceptions of a 21st Century Digital Literacy Framework. In Walden University. Walden University.

Warsah, I., \& Nuzuar, N. (2018). Analisis Inovasi Administrasi Guru dalam Meningkatkan Mutu Pembelajaran (Studi MAN Rejang Lebong). EDUKASI: Jurnal Penelitian Pendidikan Agama Dan Keagamaan, 16(3), 263-274. https://doi.org/10.32729/edukasi.v16i3.488.

Wu, Y. C. J., Pan, C. I., \& Yuan, C. H. (2017). Attitudes towards the use of information and communication technology in management education. Behaviour and Information Technology, 36(3), 243-254. https://doi.org/10.1080/0144929X.2016.1212928.

Yahya, M. D. (2017). Posisi Madrasah dalam Sistem Pendidikan Nasional di Era Otonomi Daerah. Khazanah: Jurnal Studi Islam Dan Humaniora, 12(1). https://doi.org/10.18592/khazanah.v12i1.303. 
68 | Tadbir : Jurnal Studi Manajemen Pendidikan, Vol. 5, No. 1, 2021

Yazan, B. (2015). Three Approaches to Case Study Methods in Education : Yin, Merriam, and Stake Three Approaches to Case Study Methods in Education: Yin , Merriam ,. The Qualitative Report, 20(2), 134-152. http://nsuworks.nova.edu/tqr/vol20/iss2/12. 